\title{
Article \\ Inclusive Study of Religions and World Views in Schools: Signposts from the Council of Europe
}

\author{
Robert Jackson ${ }^{1,2}$ \\ ${ }^{1}$ Centre for Education Studies, University of Warwick, Coventry, CV4 7AL, UK; E-Mail: R.Jackson@warwick.ac.uk \\ ${ }^{2}$ Department of Humanities and Social Sciences Education, Stockholm University, 10691 Stockholm, Sweden
}

Submitted: 30 October 2015 | Accepted: 16 November 2015 | Published: 19 April 2016

\begin{abstract}
This article outlines some issues in incorporating the study of religions, together with non-religious world views, into the curricula of publicly funded schools in Western democratic states. Attention is given to examples from work on this topic conducted within the Council of Europe since 2002, with a particular focus on Signposts: Policy and Practice for Teaching about Religions and Nonreligious World Views in Intercultural Education, a text published by the Council of Europe in 2014. Signposts is designed to assist policy makers and practitioners in interpreting and applying ideas from the 2008 Recommendation from the Committee of Ministers (the Foreign Ministers of the 47 member states) dealing with education about religions and non-religious convictions. Various issues raised by the Signposts document are considered. Towards the end of the article, recent UK and Council of Europe policies which emphasise the study of religions and beliefs as a means to counter extremism, and which have appeared since the publication of Signposts, are summarised and discussed critically. Attention is drawn to the dangers of certain policies, and also to the plurality of aims which studies of religions and non-religious world views need to have in providing a balanced educational programme.
\end{abstract}

\section{Keywords}

Council of Europe; education; extremism; globalisation; intercultural; pluralisation; religions; secularisation; teaching; world views

\section{Issue}

This article is part of the issue "Religious Diversity and Social Inclusion", edited by Gary Bouma (Monash University, Australia).

(C) 2016 by the author; licensee Cogitatio (Lisbon, Portugal). This article is licensed under a Creative Commons Attribution 4.0 International License (CC BY).

\section{Introduction}

The processes of secularisation, pluralisation and globalisation have encouraged debate about the place of religion in publicly funded schools, leading to policy developments and changes in the education systems of some European countries. Recently published volumes on religious education in Western Europe (Rothgangel, Jackson \& Jäggle, 2014), Northern Europe (Rothgangel, Skeie \& Jäggle, 2014) and Central Europe (Rothgangel, Schlag \& Jäggle, 2015) show the variety of education systems and approaches to religious education in various parts of Europe, but all show the ongoing influence of religious diversity upon those different systems. A further influence for change results from the debate about the place of religion in the public sphere in democracies (e.g., Habermas, 2006). For example, the shift in Council of Europe policy, which resulted in new work on the study of religion in public education from 2002, was related to that debate (Council of Europe, 2004, 2008a; Keast, 2007). A recent Council of Europe publication, Signposts: Policy and practice for teaching about religions and non-religious world views in intercultural education (Jackson, 2014a), ${ }^{1}$ acknowledges

\footnotetext{
${ }^{1}$ Available in various formats at https://book.coe.int/eur/en/ human-rights-education-intercultural-education/6101-signpostspolicy-and-practice-for-teaching-about-religions-and-non-religio us-world-views-in-intercultural-education.html in English, French and Spanish, with more translations to follow during 2016.
} 
these changes, and considers issues in developing policy and practice in this field as part of public education across Europe.

With regard to the secularisation process, in England, to take one example, secularisation was reflected in changing attitudes of young people in schools, with research carried out in the 1960s suggesting that traditional Biblical studies was felt by many older secondary school students to have limited relevance to their personal concerns (Loukes, 1965) or sometimes including an unwarranted form of religious teaching lacking breadth and opportunities for critical discussion (Cox, 1967).

Pluralisation through migration, especially since the 1960 s, led many educators to change the focus of studies of religion in fully state-funded schools from a form of single faith religious teaching to a 'nonconfessional', inclusive, multi-faith approach, including learning about the religions of relatively newly established minorities such as Hindus, Sikhs and Muslims as well as about Christianity and Judaism.

Theory and methodology from the new field of Religious Studies, which drew upon the phenomenology of religion to offer an impartial and objective approach which acknowledged increasing secularity and plurality, was influential from the early 1970s. A key source in the early stages of change was the global perspective of Ninian Smart (e.g., Smart, 1968, 1969) and the project on religious education that he led at the University of Lancaster (Schools Council, 1971). However, the relationship between Smart's theory and methodology to policy and to general practice in schools is complex and difficult to determine (Bråten, 2013). More 'bottom up' developments reflecting the increasingly multireligious and multicultural nature of British society, as experienced by students and teachers in schools, also played an important part in bringing about change in schools (Cole, 1972). With regard to fully state-funded schools (as distinct from certain categories of schools with a religious affiliation that received state funding), the changes that appeared 'bottom-up' during the 1960s and 1970s were acknowledged in law in the 1988 Education Reform Act (Dinham \& Jackson, 2012; Gates \& Jackson, 2014).

\section{The Council of Europe}

While policy makers and educators in various individual states have grappled with similar issues in their own contexts, some international institutions have become increasingly concerned with addressing issues of teaching and learning about religions and non-religious world views internationally, regarding this educational activity as highly desirable within schools in democratic societies. For example, the Organisation for Security and Co-operation in Europe (OSCE) produced a document, the Toledo Guiding Principles on Teaching about
Religions and Beliefs in Public Schools (Jackson, 2008; OSCE, 2007). Another initiative is the United Nations Alliance of Civilizations programme, which encourages education about religions and beliefs globally through its Education about Religions and Beliefs website (http://erb.unaoc.org).

Significantly more extensive than the work of the OSCE and the UN in this field is that of the Council of Europe. This on-going activity has taken place over a much longer period than the OSCE's contribution. Since 2002, the Council of Europe has given attention to education about religions (and also, since 2008, nonreligious convictions) in public schools across Europe. The earlier view of excluding the study of religions in public education-because religion was felt to belong only to the private sphere-was reconsidered. The events of September 11, 2001 in the USA were an impetus for change (Jackson, 2010).

The Council of Europe was established in 1949, a year or so after the publication of the Universal Declaration of Human Rights. Based in Strasbourg, France, the Council of Europe aims to protect human rights, pluralist democracy and the rule of law, and to seek solutions to social problems, such as xenophobia and discrimination against minorities. It also aims to promote awareness and development of Europe's cultural identity and diversity. Thus, there is an intention to develop across Europe a common commitment to the values expressed in the human rights codes - such as the value of human dignity-while at the same time respecting and valuing Europe's cultural diversity (including its religious diversity) and the traditions of each member state. There is a creative tension between a common approach to human rights and an acknowledgement of European diversity.

The Council of Europe integrates political activity with various projects undertaken under the auspices of the Council's directorates. Educational projects are conducted within the Directorate of Democratic Citizenship and Participation, which is part of the Directorate General (DGII) of Democracy. The Parliamentary Assembly of the Council of Europe consists of members of the national parliaments of member states, not members of the European Parliament. The Committee of Ministers is made up of the Foreign Ministers of all 47 member states. Periodically, the Committee of Ministers makes Recommendations to member states based on Council of Europe projects. These recommendations are not legally binding in member states, but are intended as tools for use in policy development at a national level.

The Council of Europe's educational work at school level focuses on the overlapping areas of human rights education, education for democratic citizenship and intercultural education. Cutting across these are themes such as language, history and now religion and belief. Thus, the fundamental rationale for including religion 
in the Council of Europe's educational work relates to human rights, citizenship and intercultural education. However, aims related to the personal development of students and to the intrinsic value of a broadly-based liberal education are by no means ignored. The term 'religious education' is not used in the Council of Europe documents, mainly because of its ambiguity. It can be used to describe forms of initiation into what we might call 'religious understanding', through learning and religious practice. Sometimes the terms 'religious instruction' and 'religious nurture' are used for these processes. However, 'religious education' often refers to the promotion of an inclusive, general public understanding of religion or religions - what might be termed 'understanding religion(s)'. Terms such as 'inclusive religious education' (Jackson, 2014b) or 'integrative religious education' (Alberts, 2007) are used in this way. The American Academy of Religion uses the designation 'religion education' (as distinct from 'religious education') to refer to an inclusive education about religions (American Academy of Religion, 2010). The Council of Europe documents use expressions such as 'the religious dimension of intercultural dialogue' or 'the dimension of religions.... within intercultural education', in order to avoid ambiguity. This usage carries no intention to reduce religion to culture.

\section{Towards the 2008 Council of Europe Recommendation}

In 2002, the Council of Europe launched a major project on the study of religions as part of intercultural education, entitled 'The Challenge of Intercultural Education Today: Religious Diversity and Dialogue in Europe'. There were several outputs from the project, including a book based on the papers from a conference held in Oslo (Council of Europe, 2004) and a widely distributed reference book for schools across Europe (Keast, 2007). The project influenced the Year of Intercultural Dialogue and the White Paper on Intercultural Dialogue (Council of Europe, 2008b). However, most importantly, the Committee of Ministers - the Foreign Ministers of all 47 member states-agreed, in 2008, a policy recommendation on the dimension of religions and non-religious convictions within intercultural education. The Recommendation (Council of Europe, 2008a) was circulated to all member states.

The Recommendation provides guidance on education about religions and 'non-religious convictions' in the context of intercultural education. This form of education is logically distinct from types of religious education which aim specifically to nurture children and young people in a particular faith tradition. However, the form of 'open' intercultural education suggested in the Recommendation is, in principle, complementary to many forms of outward looking faith-based education (Jackson, 2013, 2014b, 2015a). The Recommenda- tion acknowledges diversity at local, regional and international levels, and encourages connections to be made between 'local' and 'global', the exploration of issues concerning religion and identity, and the development of positive relations with parents and religious communities, as well as organisations related to nonreligious philosophies such as secular humanism. The intention is to introduce young people to a variety of positions in an atmosphere of mutual tolerance, within the 'safe space' of the classroom.

Regarding the selection of content for teaching, there is no assumption that every religious or nonreligious position should be covered in class. Selection of specific subject content needs to relate to context. There is an emphasis on competence for understanding a variety of religions and world views, including wellselected information, plus the development of skills and attitudes to facilitate intercultural and interreligious dialogue. The aim is to provide knowledge but also to encourage reciprocity, sensitivity and empathy and to combat prejudice, intolerance, bigotry and racism. Students are encouraged to engage in dialogue and discussion managed by teachers equipped with specialist knowledge and facilitation skills. Teaching and learning methods are recommended. Illustrative didactical examples include interpretive (Jackson, 1997, 2004, 2009, 2011b, 2011c; Ipgrave, Jackson, \& O'Grady, 2009; Miller, O’Grady, \& McKenna, 2013) and dialogical approaches (Ipgrave, 2013; Leganger-Krogstad, 2011), which are 'open', 'inclusive' and 'impartial' and which acknowledge the varied backgrounds of participants. The Recommendation acknowledges that such provision needs to be supported by high-quality teacher training (at both initial and in-service levels), good quality resources, and on-going research and evaluation.

Whilst having clear goals, sensitivity is expressed to the educational systems and practices already in operation in member states, and attention is drawn to the relevance of 'the already existing best practices of the respective member states'. The Recommendation is provided as an adaptable discussion text and not as an inflexible framework. Attention is also given to the fact that different approaches would be needed with young people of different ages, taking 'into account the age and maturity of pupils to whom it is addressed'.

\section{The Development of Signposts}

To maximise discussion and action in member states in relation to the Council of Europe Recommendation, the Council of Europe and European Wergeland Centre established a joint committee in 2009 to work on ways of helping policymakers and practitioners in member states to discuss and apply ideas in their own national setting. The committee included specialists in religious education and in religion in the context of intercultural education from a variety of European countries. They 
were not representing specific states, but they offered a variety of expertise which could be pooled. The committee designed and distributed a questionnaire to members of the Education Committee of the Council of Europe, based in each of the 47 member states, asking respondents to identify difficulties they felt they would have in applying the Council of Europe Recommendation in their own specific national settings.

An analysis of the questionnaire responses identified various issues which were common to many member states. These included:

- ambiguity and lack of clarity in terminology associated with teaching about religions and beliefs;

- a need to understand the component elements of 'competence' for understanding religions;

- how to make the classroom a 'safe space' for discussion and dialogue by students;

- how to help students to analyse representations of religions in the media;

- how to integrate a study of non-religious convictions and world views with the study of religions;

- how to tackle human rights issues in relation to religion and belief in schools and classrooms;

- and how to link schools to wider communities and organisations, with the goal of increasing students' knowledge about and understanding of religions and non-religious philosophies, such as secular humanism.

After much deliberation by the joint committee, and after listening to the experiences of colleagues in France, Québec, Norway and the Russian Federation, it was decided to produce a book, written primarily for policymakers and practitioners, which would explore aspects of the Recommendation in relation to the issues identified above raised by respondents to the questionnaire. The present author was given the task of writing the book on behalf of the committee, taking account of its deliberations, and drawing on relevant European and other international research, as well as giving concrete examples of experience of dealing with some of the issues in various education systems (Jackson, 2014a).

\section{Using REDCo Research}

Various research reports from the 'Religion, Education, Dialogue and Conflict' Project (REDCo), sponsored by the European Commission, proved invaluable in illustrating topics such as facilitating civil dialogue in the classroom, establishing classrooms as 'safe spaces' for dialogue, and helping young people to analyse media representations of religions (e.g., Knauth, Jozsa, Ber-
tram-Troost, \& Ipgrave, 2008; ter Avest, Jozsa, Knauth, Rosón, \& Skeie, 2009; Valk, Bertram-Troost, Frederici, \& Béraud, 2009).

With regard to linking personal concerns and social issues, REDCo research with 14-16 year olds in eight European countries (England, Estonia, France, Germany, the Netherlands, Norway, the Russian Federation and Spain) showed support from young people for education about religious diversity. The research demonstrates that studies of religious diversity are not erosive of students' own commitments, but can help to develop a culture of 'living together'. The majority of 14-16 year old young people surveyed wanted opportunities to learn about and from one another's religious perspectives in the 'safe space' of the classroom, with teachers providing knowledge and understanding while also facilitating dialogue effectively (Jackson, 2012; Knauth et al., 2008; ter Avest et al., 2009; Valk et al., 2009). Thus, studies of religions can contribute to broader fields such as intercultural education and education for democratic citizenship, as well as contributing to students' personal development and to their religious literacy. The European REDCo research shows young people who want an opportunity to learn and talk about religion in schools. They see the classroom (not family or peer group) as the only likely potential 'safe space' for this to happen, and they appreciate skilful teachers who can both provide accurate information and manage discussions which include significant differences in viewpoint. There is certainly no general assumption, as one critic has claimed, that 'all religions are equally true' (Gearon, 2013), but there is a commitment to exploring the democratic and human rights principle of freedom of religion or belief within society.

With regard to issues relating to the classroom as a safe space for dialogue, REDCo research dealt directly with addressing issues of conflict as part of such discussions. For example, Fedor Kozyrev, working in St Petersburg schools, analysed videotaped examples of classroom topics dealing with religion and conflict. He highlights the importance of the teacher's adaptability in addressing issues of conflict through dialogue, emphasizing the importance of the relationship between teacher and students, established over time (Kozyrev, 2009 , p. 215). Marie von der Lippe's research in Norwegian schools, shows how conflict can be generated by some media representations of religious material, and she suggests ways of dealing with this in class (von der Lippe, 2009, 2010). Drawing on research in Hamburg schools, Thorsten Knauth, demonstrates the importance of the teacher's awareness of the dynamics of classroom interaction between conservative Muslim students and more liberal Muslim peers influenced by values and attitudes from general youth culture. Knauth discusses how such conflicts can be addressed. He shows how well-managed classroom dialogue pro- 
vided an opportunity for pupils to test and challenge their ideas (Knauth, 2009). These examples illustrate that it is possible to provide 'safe space' for civil exchange in which issues can be discussed, and in which the expression and acceptance of difference is accommodated. Olga Schihalejev, in reporting her classroom interaction research in Estonia notes that: 'If the student recognises that security is available and trust has been built up, he or she will risk entering into conflict or vulnerable areas rather than avoiding them or utilising uncontrolled ways to deal with them' (Schihalejev, 2010, p. 177). All of this research shows that moderated, civil dialogue on topics concerned with religion, including issues of conflict, can be conducted effectively in classrooms. A necessary condition is having teachers with skills to facilitate dialogue as well as knowledge of religions.

In addition to REDCo studies, other European research used in Signposts illustrates a number of themes, such as providing examples of how schools can build educational links with religious and other communities, including the organisation of visits to religious buildings, and of the role of members of religious and belief groups in giving moderated talks about their communities in schools, in which the role of the speaker is to inform (often through personal stories) and not to prosyletise. The use of visitors from various communities as speakers in schools is discussed, including an example of partnerships between secondary schools and primary schools, in which older secondary students are trained to give information about their own faith or world view. An account of the use of ethnographic methods on outside visits in order to maximise students' understanding of others' religious language, symbols and experiences is given, and it is noted that visitors have commented on the benefit of visits to schools to them personally and to their communities. Research from Sweden and the UK reports very positive responses from secondary school students in relation to their experience of listening to outside visitors talking about religious or ethical matters or going on visits to places of worship or to places concerned with ethics in society.

\section{Signposts as a Discussion Tool}

Signposts is not a blueprint but a discussion document, written to assist practitioners and policy makers from member states (or indeed other countries) in their thinking and action in relation to their own historical and cultural context. It is concerned with increasing 'religious literacy' for the whole population-increasing tolerance, and opening up the possibility of showing respect towards others' views and values. However, even the term 'religious literacy' is used in different ways. The Council of Europe view of 'religious literacy' implies a general understanding of religious language and practice, open to everyone, which can result from learning about religions (see also American Academy of Religion, 2010; Moore, 2007). However, the term 'religious literacy' is sometimes used very differently to imply the development of a religious insider's use of religious language (Felderhof, 2012). Signposts encourages users to give careful attention to precise use of terminology, and recommends the inclusion of glossaries in documentation, so that there can be a clear, shared understanding of technical terms.

Signposts acknowledges and advocates the importance of learning about the internal diversity of religions, as well as gaining a sense of religions as distinct phenomena. It is concerned with helping learners to understand religions, but recognises that this needs to be developed in some very different educational contexts. It is clear that, in order to achieve the goals set out in Signposts, specialist teachers are needed who could also assist with the training and professional development of other teachers. The next section of the article considers a selection of issues covered in or raised by Signposts.

\section{Representing Religious and Cultural Plurality}

Signposts takes the view that representing religions as entirely homogeneous systems of belief tends to produce oversimplified, stereotypical accounts which often do not correspond to the experience of believers and practitioners (e.g., Flood, 1999; Jackson, 1997). The internal diversity of religions is acknowledged, and they can be pictured organically, for example in terms of a relationship between individuals, particular groups and wider religious traditions. It is acknowledged that the study of individuals, in relation to the various groups with which they are associated, can inform an emerging understanding of a particular religion. At the same time, key concepts from a particular religion can be exemplified and enlivened through the consideration of particular examples of religious faith and practice. This does not imply that religions cannot be thought of, in some contexts, as 'wholes'. Looking at the interplay between individuals, groups and broad traditions shows the complexity of representing religions, as well as bringing them to life, and also demonstrates how individuals relate to or fit into particular groups and specific religions. This approach also can help students and teachers to understand why a religion, as practised, for example, by a student in a class, might be different in various ways from the generic representation of that religion in a school textbook. The approach can help to alleviate the concern of some religious students, as indicated in various qualitative research studies, that their religion is misrepresented by some resources and by some teachers (Moulin, 2011).

Signposts acknowledges terminological issues and provides ideas for addressing them. With regard to is- 
sues relating to cultural plurality, there has been much debate around terms such as 'multicultural' and 'intercultural'. Some writing in the field of religions and education has worked with sophisticated formulations of multiculturalist theory, drawing on empirical research dealing with the interaction of what Gerd Baumann calls 'dominant' and 'demotic' discourses (Baumann, 1999). 'Dominant discourse' assumes the existence of distinct and separate cultures living side-by-side, often perceived as closed systems, with a fixed understanding of ethnicity. 'Demotic discourse', however, recognises 'internal diversity' of cultures (sometimes giving rise to conflict), the reality and significance of cultural fusion, the formation of new culture, intergenerational differences, and the emergence of new fundamentalisms (Jackson, 2004). Baumann's empirical research detected both forms of discourse in different contexts.

However, the rejection of multiculturalism through its identification only with 'dominant' discourse has been common among European politicians (e.g., Cameron, 2011; replied to in Jackson, 2011a). This view of multiculturalism, with its emphasis on discrete cultures, allows 'other cultures' to be perceived as rivals to the national culture. Such a one-sided representation has resulted in derogatory uses of the term 'multicultural' and avoidance of the term in some official documents, such as the final report of the UK Commission on Integration and Cohesion (Commission on Integration and Cohesion, 2007, p. 13). The Council of Europe prefers to use the term 'intercultural', with its connotations of cultural interaction and dialogue (e.g. Barrett, 2013), and regards inclusive education about religions and non-religious convictions as a subset of intercultural education (Council of Europe, 2008a; Jackson, 2014a). Some writers prefer to use the term 'diversity', rather than multiculturalism. For example, in his work on 'super-diversity' Steven Vertovec analyses the complexity and changing character of cultural and religious diversity in the light of global, regional and local factors and their relationship over time (Vertovec, 2006). This, of course, includes the emergence of socalled 'radicalised' Islam in various European contexts.

\section{Religions, or Religions and Non-Religious Convictions?}

With regard to 'pluralisation', there is an argument that an inclusive school subject should cover nonreligious philosophies as well as religions. This view was taken by the Council of Europe in its Recommendation of 2008 (Jackson, 2014a, pp. 67-75), and by the Organisation for Security and Cooperation in Europe in its Toledo Guiding Principles on Teaching about Religions and Beliefs in Public Schools (OSCE, 2007). In both cases, the argument for extending the range of 'inclusive education about religions' relates to the human rights principle of freedom of religion and belief ('belief' encompassing non-religious convictions). Signposts acknowledges the importance of debate on the topic within member states. In clarifying the ground to be discussed, Signposts makes a distinction between organised world views, such as religions and secular humanism, and personal world views of individuals. Research shows the latter often to be unconventional (e.g., Wallis, 2014). Personal world views might mirror particular religions or secular humanism, but are often more eclectic, for example, combining elements of more than one religion (e.g., Buddhism and Judaism), or features of one or more religions and Humanism (eg, bringing together an atheistic stance with elements of Christian ethics and spirituality) (Jackson 2014a, pp. 67-75). Some would argue that the school should provide opportunities for the exploration of personal as well as organised world views.

Signposts includes discussions of various other matters, such as human rights issues, and analysing media representations of religions, and invites readers to use the document in order to further discussion and action with regard to policy and practice in their own contexts.

\section{Education and Extremism: A Changing Climate}

As noted above, the events of September 11, 2001 in the United States were a catalyst for the Council of Europe's inclusion of studies of religions (and later religions and non-religious convictions) in intercultural education, but did not provide the total rationale for developments in the field. However, the climate has been changing for some time, and now a key political issue for many European democracies, is the 'radicalisation', and the extreme acts, of a small minority of people-including some young people-who, often, have been born and have grown up in those countries. For example, these might be individuals who have been prepared to commit acts of extreme violence on the basis of far right political views, as in the Breivik case in Norway (Anker \& von der Lippe, 2015), or might be from a small minority of young Muslims prepared to adopt an extremist position, supporting or committing acts of violence in their own country, or leaving home to join an extremist group in another country, such as Syria. The dreadful atrocities committed in Paris on November 13, 2015 are a vivid example of such extremism. Thus, political attention to education, especially education concerning religions, has tended to become more immediately focused on countering extremism than on wider goals.

\section{Example 1: UK Government Law and Policy}

To take one example, in the United Kingdom, extremist activity led to the 'Prevent' strategy, which was initiat- 
ed under the Labour Government, was revamped by the Coalition Government in 2011, as part of its overall counter-terrorism strategy (CONTEST), and continues as part of present Conservative Government policy. 'Prevent' focuses on: responding to the ideological challenge of terrorism and the threat from those who promote it; preventing people from being drawn into terrorism and ensuring that they are given appropriate advice and support; and working with sectors and institutions where there are risks of radicalisation that need to be addressed (retrieved from https://www.gov.uk/ government/publications/prevent-strategy-2011).

Specifically, with regard to education, non-statutory advice was published by the Department for Education in 2014 on the long-standing legal requirement that maintained schools should promote pupils' spiritual, moral, social and cultural (SMSC) development (UK Government, 2014). This non-statutory advice introduces the concept of 'British values', as articulated in the Government's 2011 development of the 'Prevent ' strategy: 'Schools should promote the fundamental British values of democracy, the rule of law, individual liberty, and mutual respect and tolerance of those with different faiths and beliefs'.

New legislation was introduced in 2015 through the Counter-Terrorism and Security Act (2015). The introduction of Part 5 of this Act gives the 'Prevent' strategy legal status in schools and colleges in England and Wales, which are now obliged by statute to have due regard' to the need to prevent people from being drawn into terrorism. Non-statutory advice to schools, published by the Department for Education in July 2015 (UK Government, 2015), explains the counter-extremism requirements, in relation to primary and secondary, state and independent schools, and includes warnings against 'non-violent extremism', and a requirement for staff to report concerns, normally through the school's safeguarding procedures; however, the option of contacting local police in order to discuss concerns is also available (UK Government, 2015, p. 10).

In May 2015, a new Counter-Extremism Bill was announced at the first meeting of a new National Security Council, chaired by the Prime Minister. This proposes new legislation to make it much harder for people to promote extremist views. The emphasis will be on bringing communities together to defeat extremism, and on promoting values (again referred to as 'British values') of freedom of speech, freedom of worship, democracy, the rule of law, and equal rights regardless of race, gender or sexuality.

\section{Example 2: Council of Europe Declaration and Action Plan}

At a European level, to take another example, the Committee of Ministers of the Council of Europe, in May 2015, issued a Declaration against Violent Extrem- ism and Radicalisation Leading to Terrorism (Council of Europe, 2015a) together with an associated Action Plan (Council of Europe, 2015b). In these documents, guiding principles on how to combat terrorism whilst respecting the rule of law and fundamental freedoms are provided by the European Convention on Human Rights and the judgments of the European Court of Human Rights. The Action Plan includes strategies to prevent and fight radicalisation, including in schools, prisons, and on the Internet. The emphasis in educational policy is on developing competences required for democratic culture and intercultural dialogue. The work already done within the Council of Europe on education about religious diversity, intercultural education, human rights education and education for democratic citizenship is deemed highly relevant to the Action Plan. There will be an emphasis on 'initiatives to combat stereotyping and discrimination, to support inclusion strategies at local level, to build trust among citizens across social and cultural differences and to support intercultural communication and skills' (Council of Europe, 2015b).

\section{Extremism and Education about Religions: Discussion}

With regard to the United Kingdom, legislation and current policy have had a mixed reception. Although the National Union of Teachers (NUT) has produced a very carefully worded advice document (NUT, 2015), the General Secretary of the Union, has stated that the 'Prevent' counter-extremism strategy was causing 'significant nervousness and confusion among teachers', and that concerns over extremism could 'close down' classroom debates which could encourage democracy and human rights (retrieved from http://www.bbc. co.uk/news/education-33328377).

According to David Anderson QC, the independent reviewer of terrorism law (https://terrorismlegislation reviewer.independent.gov.uk), the Counter Extremism Bill could provoke a backlash in Britain's Muslim communities, and risks legitimising state scrutiny of, and citizens informing on, the political activities of large numbers of law-abiding people (reported in The Guardian, 17 September 2015). One commentator satirises the proposals with an article headed 'Jesus Would Have Been Done for Extremism under This Government' (Fraser, 2015). Moreover, the specific identification of generic democratic or human rights values with a particular nationality has been criticised on a variety of grounds (e.g., Richardson \& Bolloten, 2015), especially in view of its association by some politicians with a simplistic view of multiculturalism (see section 7 above, 'Representing Religious and Cultural Plurality').

The Council of Europe's approach is more measured, and refers to democracy and human rights values, referring back to the human rights codes rather 
than associating such values with particular national traditions. The Council of Europe Declaration states:

"We are in particular convinced that education for democracy and the building of more inclusive societies are vital components of the democratic response that we must give to the upsurge in violent extremism. Restoring trust and promoting 'better living together' are challenges vital to the future of our societies." (Council of Europe, 2015a)

There is a positive emphasis on learning to live together within societies that are inclusive, rather than a preoccupation with identifying remarks and actions that could be considered as potentially extremist. Signposts is specifically mentioned as being highly relevant to helping to develop appropriate educational strategies, with the goal of 'Building Inclusive Societies': 'The Council of Europe publication Signposts, based on Recommendation CM/Rec (2008) 12 , will be widely disseminated' (Council of Europe, 2015b).

There are two key issues emerging from the policy developments outlined above that have particular relevance to education about religions and beliefs. The first is that there is a tendency for anti-extremism to become the predominant aim for studying religions, thereby excessively influencing the selection of content that relates only to this aim. The second, seen in the UK example and in the comments from its critics, is a view of anti-extremism which potentially, and inadvertently, undermines the 'democratic' justification that it claims to uphold.

With regard to addressing the first issue, it is important to combine liberal educational with instrumental personal and social reasons for learning about religions. Such a broadly based representation of religions, which acknowledges their different dimensions and their internal diversity, should encourage and inform civil classroom dialogue and discussion according to agreed ground rules, rather than focusing on extremism (Jackson, 2015b). This approach is consistent with the Council of Europe Action Plan.

With regard to dealing with the second issue, there is no escaping some degree of tension between democratic or human rights principles and some religious (and related cultural) positions. In current UK policy, which uses so-called 'British values' to support national and international security, there is a danger of slippage towards authoritarianism, and of inappropriate and potentially counter-productive actions and interpretations of policies. An appropriate way forward would be to support a more nuanced form of 'dialogical liberalism', which seeks a greater degree of dialogue between values as expressed in the human rights codes, and values that are rooted in particular religious and cultural contexts, than is to be found in some of the rhetoric of the UK Government. Care needs to be taken not to stifle all disagreement, or to oppose all alternative perspectives-including conservative religious positions-but to recognise that the limits of 'political liberalism' (Rawls, 1993) lie, not with dissent per se, but with those in society who deny the basic liberal rights of citizens or refuse to tolerate conflicting comprehensive views-in other words, those who reject the idea of political liberalism itself. On this view, non-liberal positions should be permitted, provided they do not seek to suppress alternative views. As far as possible, the state's response should be to promote discussion and dialogue, seeking what John Rawls calls 'overlapping consensus' except in clearly extreme cases, including those involving the coercion of vulnerable individuals by others or causing harm to others. At the level of social and political interaction within a society, basic human rights-as expressed in the articles of the Universal Declaration of Human Rights, rather than in any national appropriation of democratic values - provide a set of provisional moral principles, derived from reflecting on the idea of democracy itself, relevant to dialogue between those with different religious or cultural perspectives.

\section{Conclusion}

Given the increasing need for close political attention to anti-extremism, it is important, from an educational point of view, to remember that 'social instrumental' aims provide only one set of reasons for studying religions and beliefs in schools, and that anti-extremism is but one of the range of social arguments for such study. As noted earlier, there is also a strong case for including religions and beliefs as an intrinsic element of liberal education, and for regarding education about religions and beliefs as also highly relevant to students' personal development. For example, a political focus on questions of extremism should not stultify study of and reflection on the spiritual dimension of religions as one means to understanding and appreciating the life views of religious people (see, for example, Gent, 2005, 2013). Equally, policies which inhibit the kind of moderated classroom dialogue, favoured by so many young people who participated in the European Commission REDCo project, and supported enequivocally by the Council of Europe 2008 Recommendation, should be held up to close critical scrutiny.

Finally, it is worth reporting a number of recurring views which have been expressed in discussions of Signposts with teachers, teacher education students, teacher trainers, academics and policymakers in various European countries, and which reflect their knowledge and experience:

- The provision of accurate, nuanced knowledge about the religions is a necessary condition for religious literacy; thus, university courses in religious studies that provide this, together with 
skills for extending knowledge and understanding of religions, and for interreligious and intercultural dialogue, are important for the preparation of specialist teachers;

- Findings of relevant empirical research concerned with teaching about religions and non-religious convictions need to be translated into information that is available to and usable by teachers, policymakers and other professionals;

- Accounts of religious belief and non-belief need to reflect the diversity of personal world views 'on the ground', in addition to descriptions of 'organised' world views;

- Specialists in this field need to be enabled to support non-specialists and to participate in interdisciplinary approaches;

- Teachers need skills to initiate and facilitate moderated dialogue and exchange between students, based on agreed ground rules, in addition to having access to high quality information;

- Whole-school policies and practices are needed to support and sustain the general approach recommended in Signposts;

- Adequate financial resources are needed to implement the approach recommended in Signposts.

It is hoped that member states of the Council of Europe, in collaboration with the Council of Europe and with the European Wergeland Centre, will support discussion and courses based on Signposts, and will facilitate school-based research related to the main themes covered in the book.

\section{Acknowledgments}

The opinions expressed in this article are the responsibility of the author and do not necessarily reflect the official policy of the Council of Europe.

\section{Conflict of Interests}

The author declares no conflict of interests.

\section{References}

Alberts, W. (2007). Integrative religious education in Europe: A study-of-religions approach. Berlin and New York: Walter de Gruyter.

American Academy of Religion. (2010). Guidelines for teaching about religion in $\mathrm{K}-12$ public schools in the United States. Atlanta: American Academy of Religion, Religion in the Schools Task Force. Retrieved from https://www.aarweb.org/sites/default/files/ pdfs/Publications/epublications/AARK-12Curriculum Guidelines.pdf
Anker, T., \& von der Lippe, M. (2015). Coming to terms with terrorism? A case study on how schools are dealing with the terror attacks 22 July 2011 in Oslo and Utøya (Unpublished Working Paper). Hamburg: REDi project.

Barrett, M. (Ed.) (2013). Interculturalism and multiculturalism: Similarities and differences. Strasbourg: Council of Europe Publishing.

Baumann, G. (1999). The multicultural riddle: Rethinking national, ethnic and religious identities. London: Routledge.

Bråten, O. M. H. (2013). Towards a methodology for comparative studies in religious education: A study of England and Norway. Münster: Waxmann.

Cameron, D. (2011). Munich speech on 5 February on radicalisation and Islamic extremism. Retrieved from http://www.newstatesman.com/blogs/thestaggers/2011/02/terrorism-islam-ideology

Cole, W. O. (1972). Religion in the multifaith school (1st ed.). Bradford: Yorkshire Committee for Community Relations.

Commission on Integration and Cohesion. (2007). Our shared future (Final Report of the Commission on Integration and Cohesion (London), 13). Retrieved from http://resources.cohesioninstitute.org.uk/Publi cations/Documents/Document/Default.aspx?record $\mathrm{Id}=18$

Council of Europe. (2004). The religious dimension of intercultural education. Strasbourg: Council of Europe.

Council of Europe. (2008a). Recommendation CM/Rec (2008) 12 of the Committee of Ministers to Member States on the dimension of religions and nonreligious convictions within intercultural education. Retrieved from https://wcd.coe.int//ViewDoc.jsp?Ref=CM/Rec (2008)12\&Language=lanEnglish\&Ver=original\&BackC olorInternet=DBDCF2\&BackColorIntranet=FDC864\& BackColorLogged=FDC864

Council of Europe. (2008b). White paper on intercultural dialogue: Living together as equals in dignity. Strasbourg: Council of Europe Publishing.

Council of Europe. (2015a). Declaration of the Committee of Ministers of the Council of Europe, united around our principles against violent extremism and radicalisation leading to terrorism, CM(2015)74, 125th Session of the Committee of Ministers, Brussels: 19 May. Strasbourg: Council of Europe Publishing.

Council of Europe. (2015b). The fight against violent extremism and radicalisation leading to terrorism: Action Plan, CM(2015)74, 125th Session of the Committee of Ministers, Brussels, 19 May. Strasbourg: Council of Europe Publishing.

Counter-Terrorism and Security Act. (2015). Retrieved from http://www.legislation.gov.uk/ukpga/2015/6/ contents/enacted/data.htm

Cox, E. (1967). Sixth form religion: A study of the beliefs and of the attitudes to religion, religious instruction, 
and morals, of a sample of grammar school sixth form pupils. London: SCM Press.

Dinham, A., \& Jackson, R. (2012). Religion, welfare and education. In L. Woodhead \& R. Catto (Eds.), Religion and change in modern Britain (pp. 272-294). London: Routledge.

Felderhof, M. (2012). Secular humanism. In L. P. Barnes (Ed.), Debates in religious education. London: Routledge.

Flood, G. (1999). Beyond phenomenology: Rethinking the study of religion. London: Cassell.

Fraser, G. (2015, October 23). Jesus would have been done for extremism under this government. The Guardian, p. 38.

Gates, B., \& Jackson, R. (2014). Religion and education in England. In M. Rothgangel, R. Jackson, \& M. Jäggle (Eds.), Religious education at schools in Europe, Part 2: Western Europe (Wiener Forum für Theologie und Religionswissenschaft, Band 10.2, pp. 65-98). Göttingen: Vienna University Press/V\&R unipress.

Gearon, L. (2013). Masterclass in religious education: Transforming teaching and learning. London: Bloomsbury.

Gent, B. (2005). Intercultural learning: Education and Islam-A case study. In R. Jackson \& U. McKenna (Eds.), Intercultural education and religious plurality (pp. 43-52). Oslo: Oslo Coalition on Freedom of Religion or Belief, Norwegian Centre for Human Rights, University of Oslo.

Gent, B. (2013). Muslim education and the hifz process: Some images and issues. In J. Miller, K. O'Grady, \& U. McKenna (Eds.), Religion in education: Innovation in international research. (pp. 26-40). New York and London: Routledge.

Habermas, J. (2006). Religion in the public sphere. European Journal of Philosophy, 14(1), 1-25.

Ipgrave, J. (2013). The language of interfaith encounter among inner city primary school children. Religion \& Education, 40(1), 35-49.

Ipgrave, J., Jackson, R., \& O'Grady, K. (Eds). (2009). Religious education research through a community of practice. Action research and the interpretive approach. Münster: Waxmann.

Jackson, R. (1997). Religious education: An interpretive approach. London: Hodder and Stoughton.

Jackson, R. (2004). Rethinking religious education and plurality: Issues in diversity and pedagogy. London: RoutledgeFalmer.

Jackson, R. (2008). The emergence and development of the interpretive approach. In H. Streib, A. Dinter, \& K. Söderblom (Eds.), Lived religion-Conceptual, empirical and practical theological approaches: Essays in honour of Hans Günter Heimbrock. (pp. 309-322). Leiden: Brill.

Jackson, R. (2009). Studying religions: the interpretive approach in brief, retrieved from http://www.thee wc.org/library/category/view/studying.religions.the.i nterpretive.approach.in.brief

Jackson, R. (2010). Religious diversity and education for democratic citizenship: The contribution of the Council of Europe. In K. Engebretson, M. de Souza, G. Durka, \& L. Gearon (Eds.), International handbook of inter-religious education, volume 4: Religion, citizenship and human rights (pp. 1121-1151). Dordrecht, the Netherlands: Springer Academic Publishers.

Jackson, R. (2011a). Cameron, 'multiculturalism' and education about religions and belief. Retrieved from http://www.ekklesia.co.uk/node/14271

Jackson, R. (2011b). The interpretive approach as a research tool: inside the REDCo project. British Journal of Religious Education, 33(2), 189-208.

Jackson, R. (2011c). The interpretive approach to religious education in a social studies context in publicly funded schools. In B. Schullerqvist (Ed.), Patterns of research in civics, history, geography and religious education (Studier i de samhällsvetenskapligaämnenasdidaktik nr 14., pp. 145-163) Karlstad: Karlstad University Press.

Jackson, R. (2012). (Ed.), Religion, education, dialogue and conflict: perspectives on religious education research. London: Routledge.

Jackson, R. (2014a). Signposts: Policy and practice for teaching about religions and non-religious world views in intercultural education. Strasbourg: Council of Europe Publishing.

Jackson, R. (2014b). Addressing religious extremism: A positive approach for policy makers and practitioners. In T. Thorp \& D. Cere (Eds.), Religion and conflict: Responding to the challenges (pp. 70-77). London: Tony Blair Faith Foundation. Retrieved from http://tonyblairfaithfoundation.org/foundation/new s/addressing-religious-extremism-positive-approachpolicy-makers-and-practitioners

Jackson, R. (2015a). Misrepresenting religious education's past and present in looking forward: Gearon using Kuhn's concepts of paradigm, paradigm shift and incommensurability. Journal of Beliefs and Values: Studies in Religion \& Education, 36(1), 64-78.

Jackson, R. (2015b). The politicisation and securitisation of religious education? a rejoinder, British Journal of Educational Studies, Special Issue on Education, Security and Intelligence Studies, 63(3), 345-366.

Keast, J. (Ed.). (2007). Religious diversity and intercultural education: A reference book for schools. Council of Europe Publishing: Strasbourg.

Knauth T. (2009). Dialogue on a grassroots-level: Analysing dialogue-oriented classroom interaction in Hamburg RE. In I. ter Avest, D.-P. Jozsa, T. Knauth, J. Rozon, \& G. Skeie (Eds.), Dialogue and conflict on religion: Studies of classroom interaction in European countries (pp. 110-134). Münster: Waxmann.

Knauth, T., Jozsa, D-P., Bertram-Troost, G., \& Ipgrave, J. (Eds.). (2008). Encountering religious pluralism in school and society. A qualitative study of teenage 
perspectives in Europe. Münster: Waxmann.

Kozyrev, F. (2009). Dialogues about religion-Incident analysis of classroom interaction in St Petersburg. In I. ter Avest, D.-P. Jozsa, T. Knauth, J. Rozon, \& G. Skeie (Eds.), Dialogue and conflict on religion: Studies of classroom interaction in European countries (pp. 199-244). Münster: Waxmann.

Leganger-Krogstad, H. (2011). The religious dimension of intercultural education: Contributions to a contextual understanding. Berlin: LIT Verlag.

Loukes, H. (1965). New ground in Christian education. London: SCM Press.

Miller, J., O’Grady, K., \& McKenna, U. (Eds.). (2013). Religion in education: Innovation in international research. New York and London: Routledge.

Moore, D. (2007). Overcoming religious illiteracy: A cultural studies approach to the study of religion in secondary education. New York: Palgrave Macmillan.

Moulin, D. (2011). Giving voice to "the silent minority": The experience of religious students in secondary school religious education lessons, British Journal of Religious Education, 33(3), 313-326.

National Union of Teachers. (2015). Education and extremism: Advice for members in England and Wales. London: National Union of Teachers. Retrieved from http://www.mta-uk.org/wpcontent/uploads/2015/06/prevent-strategy.pdf

Organisation for Security and Co-operation in Europe. (2007). The Toledo guiding principles on teaching about religions and beliefs in public schools. Warsaw: Organisation for Security and Co-operation in Europe, Office for Democratic Institutions and Human Rights. Retrieved from http://www.osce.org/odihr/ 29154

Rawls, J. (1993). Political liberalism. New York: Columbia University Press.

Richardson, R., \& Bolloten, B. (2015). 'Fundamental British values' origins, controversy, ways forward: A symposium, compiled for Race Equality Teaching. Retrieved from http://www.insted.co.uk/britishvalues.pdf

Rothgangel M., Jackson R., \& Jäggle M. (Eds.). (2014). Religious education at schools in Europe. Volume 2: Western Europe (Wiener Forum für Theologie und Religionswissenschaft, Band 10.2). Göttingen: Vienna University Press/V\&R unipress.

Rothgangel, M., Schlag, T., \& Jäggle, M. (Eds.). (2015). Religious education at schools in Europe. Volume 1: Central Europe (Wiener Forum für Theologie und Religionswissenschaft, Band 10.1). Göttingen: Vienna University Press/V\&R unipress.

Rothgangel M., Skeie G., \& Jäggle M. (Eds.) (2014). Religious education at schools in Europe. Volume 3:
Northern Europe (Wiener Forum für Theologie und Religionswissenschaft, Band 10.3). Göttingen: Vienna University Press/V\&R unipress.

Schihalejev, O. (2010). From indifference to dialogue? Estonian young people, the school and religious diversity. Münster: Waxmann.

Schools Council. (1971). Religious education in secondary schools. London: Evans Methuen.

Smart, N. (1968). Secular education and the logic of religion. London: Faber.

Smart, N. (1969). The religious experience of mankind. London: Collins.

ter Avest, I., Jozsa, D-P., Knauth, T., Rosón, J., \& Skeie, G. (Eds.). (2009). Dialogue and conflict on religion. Studies of classroom interaction on European countries. Waxmann: Münster.

UK Government. (2014). Promoting fundamental British values as part of SMSC in school. Departmental advice for maintained schools. London: Department for Education. Retrieved from https://www.gov.uk/ government/uploads/system/uploads/attachment _data/file/380595/SMSC_Guidance_Maintained_Sch ools.pdf

UK Government. (2015). The Prevent duty. Departmental advice for schools and childcare providers. London: Department for Education. Retrieved from https:// www.gov.uk/government/uploads/system/uploads/ attachment_data/file/439598/prevent-duty-depart mental-advice-v6.pdf

Valk, P., Bertram-Troost, G., Frederici, M., \& Béraud, C. (Eds.). (2009). Teenagers' perspectives on the role of religion in their lives, schools and societies: A European quantitative study. Waxmann: Münster.

Vertovec, S. (2006). The emergence of super-diversity in Britain (Centre on Migration, Policy and Society, Working Paper No. 25). Oxford: University of Oxford. Retrieved from http://www.compas.ox.ac.uk/filead $\mathrm{min} /$ files/pdfs/Steven\%20Vertovec\%20WP0625.pdf

von der Lippe, M. (2009). Scenes from a classroom: Video analysis of classroom interaction in religious education in Norway. In I. ter Avest, D.-P. Jozsa, T. Knauth, J. Rozon, \& G. Skeie (Eds.), Dialogue and conflict on religion: Studies of classroom interaction in European countries. (pp. 174-193). Waxmann: Münster.

von der Lippe, M. (2010). Youth, religion and diversity. A qualitative study of young people's talk about religion in a secular and plural society: A Norwegian case (Unpublished PhD Disseration). Stavanger, University of Stavanger, Norway.

Wallis, S. (2014). Ticking "no religion": A case study amongst "young nones". Diskus, 16(2), 70-87. 


\section{About the Author}

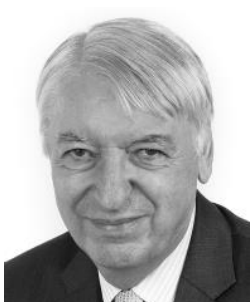

\section{Dr. Robert Jackson}

Robert Jackson was Director of Warwick Religions and Education Research Unit (1994-2012) and is Emeritus Professor of Religions and Education at the University of Warwick, and Visiting Professor in the Department of Humanities and Social Sciences Education at Stockholm University. He has been involved since 2002 in the Council of Europe's work on religions and intercultural education, and was Special Adviser to the European Wergeland Centre 2009-2014, holding a Visiting Professorship at Oslo University College. 